\title{
Isolation and Characterization of a Thermophilic Sulfate-Reducing Bacterium, Desulfotomaculum thermosapovorans sp. nov.
}

\author{
MARIE-LAURE FARDEAU, ${ }^{1,2 *}$ BERNARD OLLIVIER, ${ }^{2}$ BHARAT K. C. PATEL, ${ }^{2,3}$ PREM DWIVEDI, ${ }^{3}$ \\ MICHEL RAGOT, ${ }^{2}$ AND JEAN-LOUIS GARCIA ${ }^{2}$ \\ Laboratoire de Chimie Bactérienne, Centre National de la Recherche Scientifique, 13277 Marseille cedex $9,{ }^{1}$ and \\ Laboratoire de Microbiologie ORSTOM, Université de Provence, 13331 Marseille cedex $3{ }^{2}$ France, and \\ Faculty of Science and Technology, Griffith University, Brisbane, Queensland 4111, Australia ${ }^{3}$
}

\begin{abstract}
Strain $M{ }^{\mathrm{T}}$ ( $\mathrm{T}=$ type strain), a new thermophilic, spore-forming sulfate-reducing bacterium, was characterized and was found to be phenotypically, genotypically, and phylogenetically related to the genus Desulfotomaculum. This organism was isolated from a butyrate enrichment culture that had been inoculated with a mixed compost containing rice hulls and peanut shells. The optimum temperature for growth was $50^{\circ} \mathrm{C}$. The G+C content of the DNA was $51.2 \mathrm{~mol} \%$. Strain $\mathrm{MLF}^{\mathrm{T}}$ incompletely oxidized pyruvate, butyrate, and butanol to acetate and presumably $\mathrm{CO}_{2}$. It used long-chain fatty acids and propanediols. We observed phenotypic and phylogenetic differences between strain $\mathrm{MLF}^{\mathrm{T}}$ and other thermophilic Desulfotomaculum species that also oxidize long-chain fatty acids. On the basis of our results, we propose that strain $M_{L F}{ }^{T}$ is a member of a new species, Desulfotomaculum thermosapovorans.
\end{abstract}

In environments where conditions for the survival of the strictly anaerobic sulfate-reducing bacteria are not provided continuously, the sporulating species of the genus Desulfotomaculum are usually dominant (2). In recent years, several species of this genus have been isolated from thermal ecosystems $(3,22)$. Anaerobic degradation of fatty acids by sulfatereducing bacteria has been investigated primarily by using members of the genus Desulfotomaculum. The following five thermophilic species oxidize these compounds: Desulfotomaculum kuznetsovii (15), Desulfotomaculum geothermicum (3), Desulfotomaculum thermoacetoxidans (14), Desulfotomaculum thermobenzoicum (22), and Desulfotomaculum australicum (11). D. australicum uses acetate. In addition to acetate, $D$. thermoacetoxidans uses propionate. D. thermobenzoicum oxidizes propionate and butyrate, while D. geothermicum and D. kuznetsovii use long-chain fatty acids (LCFA). In contrast to utilization of LCFA, oxidation of propanediols has been poorly studied with members of the genus Desulfotomaculum. D. thermobenzoicum has been reported to use 1,2-propanediol and 1,3-propanediol (22), but the products of metabolism have not been identified.

In this paper we describe a new spore-forming, thermophilic, sulfate-reducing bacterium (strain $\mathrm{MLF}^{\mathrm{T}}$ [T = type strain]) which degrades LCFA and propanediols. Because of significant differences in physiological, phylogenetic, and metabolic properties between this isolate and other members of the genus Desulfotomaculum, we propose that strain $\mathrm{MLF}^{\mathrm{T}}$ should be placed in a new species, Desulfotomaculum thermosapovorans.

\section{MATERIALS AND METHODS}

Sources of organisms. Strain $\mathrm{MLF}^{\mathrm{T}}$ was isolated from a thermophilic anaerobic enrichment culture growing on rice hulls at $55^{\circ} \mathrm{C}$. The initial inoculum was a mixed compost containing rice hulls and peanut shells.

D. geothermicum DSM 3669 was grown by using the media and conditions described by Daumas et al. (3).

Media. Growth media were prepared by using the technique of Hungate (7).

${ }^{*}$ Corresponding author. Mailing address: Laboratoire de Microbiologie ORSTOM, Université de Provence, 3 Place Victor Hugo, 13331 Marseille cedex 3, France. Phone: (33) 91.10.64.80. Fax: (33) 91.10. 64.81 .
The organisms were cultivated under strictly anoxic conditions at $55^{\circ} \mathrm{C}$. The basal medium contained (per liter of distilled water) $1.0 \mathrm{~g}$ of $\mathrm{NH}_{4} \mathrm{Cl}, 0.15 \mathrm{~g}$ of $\mathrm{CaCl}_{2} \cdot 2 \mathrm{H}_{2} \mathrm{O}, 1 \mathrm{~g}$ of NaCl, $0.5 \mathrm{~g}$ of KCl, $0.4 \mathrm{~g}$ of $\mathrm{MgCl}_{2} \cdot 6 \mathrm{H}_{2} \mathrm{O}, 0.2 \mathrm{~g}$ of $\mathrm{KH}_{2} \mathrm{PO}_{4}$, $1.0 \mathrm{~g}$ of $\mathrm{CH}_{3} \mathrm{COONa} \cdot 3 \mathrm{H}_{2} \mathrm{O}, 0.001 \mathrm{~g}$ of resazurin, $1 \mathrm{ml}$ of a sodium selenite solution (17), and $1.5 \mathrm{ml}$ of a trace mineral solution (8); the $\mathrm{pH}$ of this medium was 7.0. The basal medium was boiled under a stream of $\mathrm{O}_{2}$-free $\mathrm{N}_{2}$ and cooled to room temperature, and 5-ml portions were distributed into Hungate tubes under an $\mathrm{N}_{2}-\mathrm{CO}_{2}(80: 20)$ gas mixture. After the tubes were autoclaved at $110^{\circ} \mathrm{C}$ for $30 \mathrm{~min}, 0.05 \mathrm{ml}$ of $\mathrm{Na}_{2} \mathrm{~S} \cdot 9 \mathrm{H}_{2} \mathrm{O}, 0.2 \mathrm{ml}$ of $10 \% \mathrm{NaHCO}_{3}$ (sterile, anaerobic solution), $0.05 \mathrm{ml}$ of a filter-sterilized vitamin solution (26), and $0.05 \mathrm{ml}$ of $0.1 \%$ dithionite solution were added to each tube just before inoculation. To isolate pure cultures, solid medium for roll tubes was prepared by adding $2 \%$ (wt/vol) Noble agar (Difco Laboratories, Detroit, Mich.) to the growth medium.

Culture purity. Cultures were routinely checked for purity by microscopic examination; to do this, we used cultures grown in aerobic and anaerobic liquid media containing $20 \mathrm{mM}$ glucose and $0.2 \%$ yeast extract at 35 and $55^{\circ} \mathrm{C}$.

Substrate utilization. Substrate utilization was determined with duplicate preparations by using the basal growth medium described above. The substrates (which were prepared as autoclaved or filter-sterilized stock solutions and stored under $\mathrm{N}_{2}$ ) were added to autoclaved media so that the final substrate concentrations were between 5 and $20 \mathrm{mM}$, depending on the substrate used. Growth was determined by measuring optical density and sulfide production after 1 week of incubation (see below).

Analytical methods. Optical density at $580 \mathrm{~nm}$ was determined with a model UV-160A spectrophotometer (Shimadzu Corp., Kyoto, Japan). Sulfide production was determined by the method described by Cord-Ruwisch (1). Volatile fatty acid and alcohol contents were determined by gas chromatography at $170^{\circ} \mathrm{C}$ by using a Poraplot Q capillary column (Chrompack France, Les Ulis, France) connected to a flame ionization detector (model CP 9000; Chrompack France); $\mathrm{N}_{2}$ was used as the carrier gas. Prior to injection, the culture supernatants were acidified by adding $50 \%$ (vol/vol) $\mathrm{H}_{3} \mathrm{PO}_{4}$. Propanediol and 3-hydroxypropionate contents were determined by high-performance liquid chromatography by using an ORH 801 column (length, $250 \mathrm{~mm}$; diameter, $4.1 \mathrm{~mm}$; Interaction Chemicals, Inc., Mountain View, Calif.) and a model RID-6A detector (Shimadzu).

DNA base composition. Cells were lysed with sodium dodecyl sulfate, and DNA was purified from the cell lysate by the method of Marmur (12). The buoyant density of the DNA was determined by centrifugation with a Beckman model $\mathrm{E}$ centrifuge in a cesium chloride density gradient, using the methods of Meselson and Stahl (13) and Szybalski (21). The density of the cesium chloride was determined with a digital precision densitometer (model DMA 02C; Anton Paar) by using the method of Stabineer (20).

16S rRNA gene sequence studies. DNAs were extracted from strain $M L F^{T}$ and D. geothermicum, and then the 16S rRNA gene was amplified and purified as described previously $(11,18)$. The sequence of the purified PCR product was determined directly or after the product was cloned. The method used to clone the 16S rRNA genes has been described previously (11). Sequences were determined with a model ABI 373A automated DNA sequencer by using prism dideoxy terminator protocols (Applied Biosystems, Ltd.). The primers used for sequencing have also been described previously (18).

16S rRNA sequences were obtained from the Ribosomal RNA Database Project and from GenBank and EMBL. The $16 \mathrm{~S}$ ribosomal DNA sequences were aligned with the sequences of various members of the bacterial phylum by using 


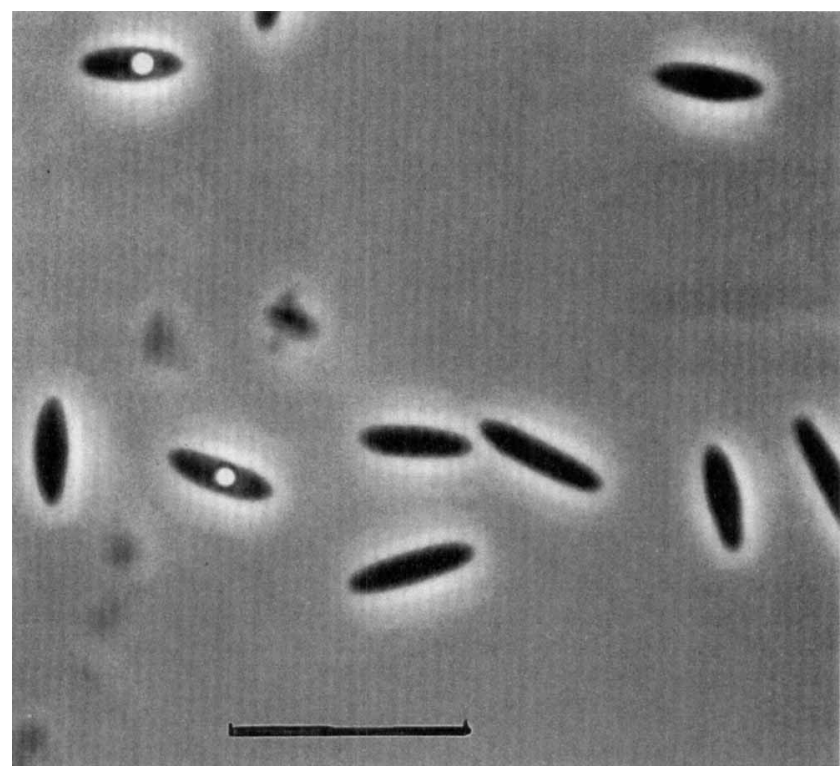

FIG. 1. Photomicrograph of strain $\mathrm{MLF}^{\mathrm{T}}$ cells, showing the central to subterminal position of spores. Bar $=10 \mu \mathrm{m}$.

alignment editor ae2 (16). Positions at which the sequence and/or alignment was uncertain were omitted from the analysis (positions 1 to 107,213 to 235,469 to 497,526 to 573,856 to 867,921 to 1063,1207 to 1248 , and 1382 to 1542 ; Escherichia coli numbering of Winker and Woese [27]). Pairwise evolutionary distances were determined from percentages of similarity by using the correction factor of Jukes and Cantor (10). Dendrograms were constructed from evolutionary distances by using the program of De Soete (4). Tree topology was reexamined by using 100 bootstrapped data sets. The SEQQBOOT, DNADIST, FITCH, and CONSENS programs available in the PHYLIP package (5) and other programs available in the TREECON package (23) were used for this purpose.

Nucleotide sequence accession numbers. The sequence of the 16S rRNA gene of strain $\mathrm{MLF}^{\mathrm{T}}$ has been deposited in the EMBL database under accession number $\mathrm{Z} 26315$, and the sequence of the $16 \mathrm{~S}$ rRNA gene of $D$. geothermicum has been deposited under accession number X80789. The accession numbers for the Thermoanaerobacter thermohydrosulfuricus, Thermoanaerobacter brockii, Propionigenium modestum, Desulfotomaculum nigrificans, Desulfotomaculum orientis, and $D$. thermobenzoicum sequences which we used were L09161, L09165, X54275, X62176, M34417, and L15628, respectively.

\section{RESULTS}

Enrichment and isolation. A mixed compost containing rice hulls and peanut shells was incubated anaerobically at $55^{\circ} \mathrm{C}$. The resulting enrichment culture was transferred several times into bottles containing only rice hulls. For the last transfer we used a medium containing butyrate as the energy source and sulfate as an electron acceptor. In this enrichment culture the dominant microbial population consisted of sporulating rods. Pasteurization of the enrichment culture at $90^{\circ} \mathrm{C}$ for $30 \mathrm{~min}$ followed by dilution in agar tubes led to development of colonies within 2 weeks with incubation at $55^{\circ} \mathrm{C}$. Pure cultures were obtained from single colonies after pasteurization as described above, and the agar shake dilution procedure was repeated several times. The resulting pure culture was designated $M F^{\mathrm{T}}$ and characterized.

Morphology. The vegetative cells of strain $\mathrm{MLF}^{\mathrm{T}}$ were straight or slightly curved motile rods (Fig. 1). Spores in central positions were also observed (Fig. 1). The cells were 1.5 to 2 $\mu \mathrm{m}$ in diameter and 5 to $8 \mu \mathrm{m}$ long and occurred singly or in pairs. No gas vacuoles were observed.

Growth characteristics. Strain $\mathrm{MLF}^{\mathrm{T}}$ grew at temperatures between 35 and $60^{\circ} \mathrm{C}$. The optimum temperature was $50^{\circ} \mathrm{C}$.
TABLE 1. Products formed during growth of strain $\mathrm{MLF}^{\mathrm{T}}$ on different substrates in the presence of sulfate

\begin{tabular}{lccl}
\hline Substrate & $\begin{array}{c}\text { Substrate } \\
\text { concn } \\
(\mathrm{mM})\end{array}$ & $\begin{array}{c}\text { Concn of acetate } \\
\text { produced } \\
(\mathrm{mM})\end{array}$ & $\begin{array}{c}\text { Other product } \\
\text { formed }\end{array}$ \\
\hline Pyruvate & 20 & 19.3 & \\
Butanol & 20 & 19.8 & \\
Butyrate & 20 & 19.2 & Propionate \\
1-Propanol & 20 & 0 & \\
$\mathrm{H}_{2}-\mathrm{CO}_{2}$ & $-a$ & 0 & Isobutyrate \\
Ethanol & 20 & 19.8 & \\
Isobutanol & 20 & 0 & 3-Hydroxypropionate \\
1,2-Propanediol & 10 & 9.8 & \\
1,3-Propanediol & 10 & 0 & \\
\hline
\end{tabular}

${ }^{a}-$, an excess of $\mathrm{H}_{2}-\mathrm{CO}_{2}$ was present.

The optimum $\mathrm{pH}$ for growth was between 7.2 and 7.5. This isolate did not require complex organic nutrients such as yeast extract or Bacto Peptone and did not grow after four subcultures without added vitamins. It grew in medium containing 0 to $35 \mathrm{~g}$ of $\mathrm{NaCl}$ per liter; optimum growth occurred in medium containing $15 \mathrm{~g}$ of $\mathrm{NaCl}$ per liter. In the presence of sulfate, strain MLF ${ }^{\mathrm{T}}$ utilized butyrate and LCFA $\left(\mathrm{C}_{5}, \mathrm{C}_{6}, \mathrm{C}_{7}, \mathrm{C}_{8}, \mathrm{C}_{9}\right.$, $\mathrm{C}_{12}, \mathrm{C}_{16}, \mathrm{C}_{18}, \mathrm{C}_{20}$, and $\mathrm{C}_{22}$ fatty acids). It also used the following substrates as energy sources: methanol, ethanol, 1-propanol, butanol, isobutanol, pentanol, lactate, pyruvate, malate, fumarate, 1,2-propanediol, and 1,3-propanediol. It utilized formate and $\mathrm{H}_{2}-\mathrm{CO}_{2}$ as sole carbon and energy sources; it reduced sulfate to sulfide and did not produce acetate during growth on sulfate. Strain MLF $^{\mathbf{T}}$ converted butanol, pyruvate, ethanol, butyrate, and 1,2-propanediol to acetate in the presence of sulfate (Table 1). Isobutanol was oxidized to isobutyrate, while 1,3-propanediol was oxidized to 3-hydroxypropionate and 1-propanol was oxidized to propionate (Table 1).

The substrates tested but not used were acetate, propionate, succinate, isobutyrate, 2-propanol, fructose, glucose, xylose, benzoate, $p$-hydroxybenzoate, 3,5-, 2,6-, and 2,4-dihydroxybenzoates, 3,4,5-trihydroxybenzoate, and glycerol.

Lactate and pyruvate were also used without added electron acceptors.

In the presence of butyrate, strain $\mathrm{MLF}^{\mathrm{T}}$ was able to grow by using sulfate, sulfite, and thiosulfate as electron acceptors. Sulfur was not used as an electron acceptor.

$\mathbf{G}+\mathbf{C}$ content. The DNA guanine-plus-cytosine $(\mathrm{G}+\mathrm{C})$ content of the isolate, as determined by ultracentrifugation, was $51.2 \mathrm{~mol} \%$.

Phylogeny. We sequenced 1,529 and 1,522 bases from position 8 to position 1542 (E. coli numbering of Winker and Woese [27]) of the 16S rRNA genes of strain $\mathrm{MLF}^{\mathrm{T}}$ and $D$. geothermicum, respectively. The $\mathrm{G}+\mathrm{C}$ content of both $16 \mathrm{~S}$ rRNA genes was $57.44 \mathrm{~mol} \%$. Sequence alignment followed by a phylogenetic analysis in which we compared these rRNA gene sequences with the sequences of representatives of the domain Bacteria revealed that strain $\mathrm{MLF}^{\mathrm{T}}$ belonged to the subphylum containing gram-positive bacteria having $\mathrm{G}+\mathrm{C}$ contents less than $55 \mathrm{~mol} \%$. Further analysis with members of the low-G+C-content branch revealed that strain $\mathrm{MLF}^{\mathrm{T}}$ was related to the thermophilic sulfate-reducing species belonging to the genus Desulfotomaculum, including $D$. geothermicum (level of similarity, 93\%) and D. australicum and D. thermobenzoicum (level of similarity, $89 \%$ ); these three species, in turn, were related to the moderately thermophilic organism $D$. nigrificans and the mesophilic sulfate-reducing species Desulfotomaculum ruminis (average level of similarity, 88\%). The 


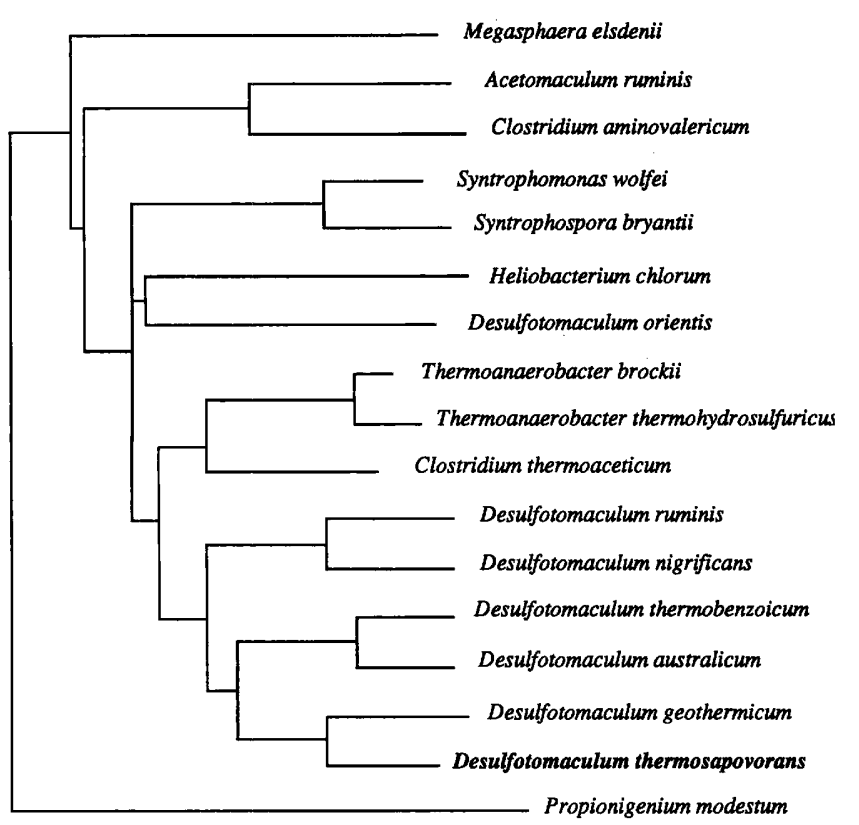

0.1

FIG. 2. Phylogenetic position of $D$. thermosapovorans within the radiation of gram-positive bacteria having DNA G+C contents less than $55 \mathrm{~mol} \%$. five Desulfotomaculum species were peripherally related to $D$. orientis (level of similarity, $86 \%$ ). Figure 2 is a dendrogram generated from the matrix in Table 2 and shows these relationships. A bootstrap analysis of the data, as implemented in the PHYLIP package (5) and TREECON package (23), gave similar results.

\section{DISCUSSION}

Strain $\mathrm{MLF}^{\mathrm{T}}$ is unique among the spore-forming, thermophilic, sulfate-reducing bacteria in that it grows on 1,2-propanediol and 1,3-propanediol and produces acetate and 3-hydroxypropionate, respectively, from these substrates. The only other organism that grows on these compounds is $D$. thermobenzoicum, but the end products from growth on these substrates have not been studied (22).

In anoxic sewage digesters, significant amounts of neutral fats and LCFA are present, in addition to carbohydrates, proteins, and lipids (6). Therefore, LCFA oxidizers are ecologically important in such ecosystems. In the absence of sulfate, and in methanogenic environments, LCFA are oxidized to methane and carbon dioxide via $\beta$-oxidation only when this process is coupled to interspecies $\mathrm{H}_{2}$ transfer $(9,24)$. For example, a syntrophic association of Methanospirillum hungatei with Syntrophomonas sapovorans is able to oxidize fatty acids (up to $\mathrm{C}_{18}$ fatty acid) to methane and acetate (19). In the presence of sulfate, a few Desulfotomaculum species have the ability to use LCFA, but only two of these organisms are thermophilic (D. geothermicum [3] and D. kuznetsovii [15]). However, strain $\mathrm{MLF}^{\mathrm{T}}$, D. geothermicum, and D. kuznetsovii

TABLE 2. Evolutionary similarity matrix for various gram-positive bacteria obtained by using the method of Jukes and Cantor ${ }^{a}$

\begin{tabular}{|c|c|c|c|c|c|c|c|c|c|c|c|c|c|c|c|c|}
\hline \multirow[b]{2}{*}{ Species } & \multicolumn{16}{|c|}{$\%$ Sequence similarity to: } \\
\hline & 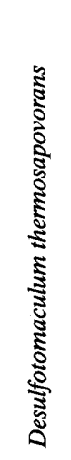 & 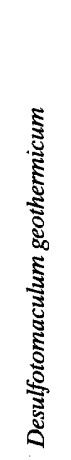 & 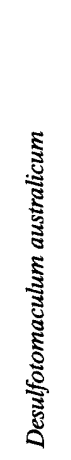 & 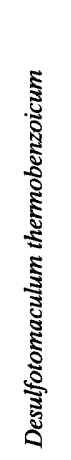 & 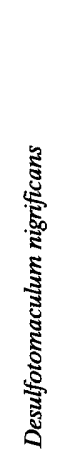 & 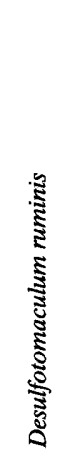 & 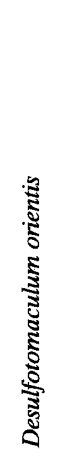 & 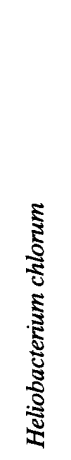 & 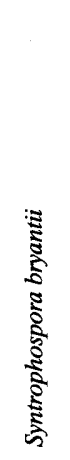 & 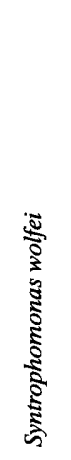 & 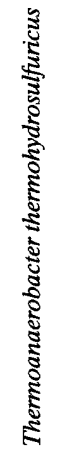 & 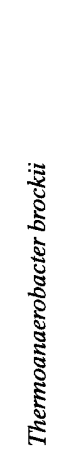 & 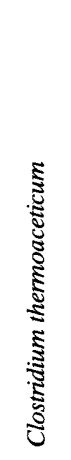 & 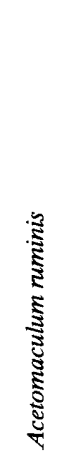 & 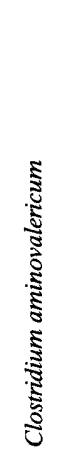 & 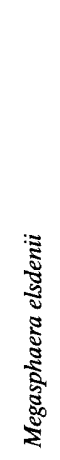 \\
\hline Desulfotomaculum geothermicun & 93.4 & & & & & & & & & & & & & & & \\
\hline Desulfotomaculum australicum & 89.6 & 88.8 & & & & & & & & & & & & & & \\
\hline Desulfotomaculum thermobenzoicum & 89.5 & 89.4 & 95.3 & & & & & & & & & & & & & \\
\hline Desulfotomaculum nigrificans & 88.2 & 87.4 & 87.7 & 88.2 & & & & & & & & & & & & \\
\hline Desulfotomaculum ruminis & 88.4 & 87.8 & 86.9 & 87.0 & 93.5 & & & & & & & & & & & \\
\hline Desulfotomaculum orientis & 86.4 & 85.3 & 85.6 & 84.6 & 84.8 & 85.0 & & & & & & & & & & \\
\hline Heliobacterium chlorum & 85.6 & 84.0 & 83.7 & 83.7 & 84.9 & 85.8 & 85.0 & & & & & & & & & \\
\hline Syntrophospora bryantii & 82.5 & 81.8 & 85.9 & 84.8 & 82.8 & 83.5 & 84.4 & 84.4 & & & & & & & & \\
\hline Syntrophomonas wolfei & 83.9 & 82.9 & 86.1 & 85.0 & 83.5 & 83.6 & 85.0 & 84.1 & 94.3 & & & & & & & \\
\hline Thermoanaerobacter thermohydrosulfuricus & 86.5 & 86.5 & 87.8 & 87.9 & 85.0 & 85.6 & 85.3 & 84.5 & 86.4 & 86.8 & & & & & & \\
\hline Thermoanaerobacter brockii & 87.2 & 86.8 & 88.5 & 88.5 & 85.4 & 86.3 & 85.4 & 85.1 & 86.7 & 87.2 & 97.5 & & & & & \\
\hline Clostridium thermoaceticum & 88.8 & 88.5 & 88.8 & 89.8 & 87.4 & 85.7 & 86.3 & 83.8 & 85.9 & 87.0 & 90.5 & 90.9 & & & & \\
\hline Acetomaculum ruminis & 82.7 & 83.4 & 82.0 & 82.5 & 82.3 & 81.9 & 81.9 & 81.9 & 82.1 & 82.5 & 83.2 & 84.4 & 84.2 & & & \\
\hline Clostridium aminovalericum & 81.7 & 81.0 & 81.0 & 81.9 & 83.1 & 82.2 & 82.0 & 81.1 & 84.5 & 83.7 & 82.7 & 83.5 & 83.9 & 89.5 & & \\
\hline Megasphaera elsdenii & 83.5 & 82.7 & 81.9 & 82.2 & 82.6 & 82.3 & 82.7 & 80.8 & 81.1 & 81.8 & 84.2 & 84.6 & 85.2 & 83.0 & 81.8 & \\
\hline Propionigenium modestum & 77.7 & 77.0 & 76.9 & 77.0 & 77.2 & 78.2 & 78.5 & 78.0 & 77.8 & 78.2 & 78.0 & 78.3 & 78.8 & 77.7 & 77.0 & 78.3 \\
\hline
\end{tabular}

${ }^{a}$ Some of the sequences used in this analysis were obtained from the Ribosomal RNA Database Project, version 2 (16). Additional sequences not available in this database were obtained from GenBank or EMBL, including the T. thermohydrosulfuricus, T. brockii, P. modestum, D. nigrificans, D. orientis, and D. thermobenzoicum sequences. Only 895 unambiguous nucleotides were used in the analysis. See text. 
differ markedly phenotypically. In contrast to strain $\mathrm{MLF}^{\mathrm{T}}, D$. kuznetsovii uses acetate and propionate and has a higher optimum temperature for growth $\left(65^{\circ} \mathrm{C}\right)$. We were not able to compare the phylogenetic position of $D$. kuznetsovii as a culture of this organism was not available. However, the physiological data provide evidence that strain $\mathrm{MLF}^{\mathrm{T}}$ is different from $D$. kuznetsovii. Strain MLF $^{\mathrm{T}}$ differs from $D$. geothermicum in that it does not utilize propionate or sugars (fructose) but uses methanol and heptanoate, does not possess gas vacuoles, and grows in the presence of a different range of $\mathrm{NaCl}$ concentrations ( 0 to $35 \mathrm{~g} /$ /iter for strain $\mathrm{MLF}^{\mathrm{T}}$ and 2 to $50 \mathrm{~g} /$ liter for $D$. geothermicum). Phylogenetic evidence also indicates that strain $\mathrm{MLF}^{\mathrm{T}}$ and $D$. geothermicum are distinct species. There are also considerable phylogenetic differences between strain $M F^{\mathbf{T}}$ and the other physiologically distinct non-LCFA-degrading thermophilic Desulfotomaculum species, including $D$. thermobenzoicum (22), D. nigrificans (25), and D. australicum (11). In conclusion, strain MLF $^{\mathbf{T}}$ is not a member of a previously described Desulfotomaculum species. We propose that this organism belongs to new species, Desulfotomaculum thermosapovorans.

Description of Desulfotomaculum thermosapovorans sp. nov. Desulfotomaculum thermosapovorans (ther.mo.sa.po.vo'rans. Gr. adj. thermos, hot; M. L. neut. n. sapo, soap; L. v. voro, to devour; M.L. part. adj. sapovorans, soap devouring; M. L. part. adj. thermosapovorans, thermophilic and soap devouring). Rod-shaped cells are 1.5 to $2 \mu \mathrm{m}$ in diameter and 5 to $8 \mu \mathrm{m}$ long and occur singly or in pairs. The cells are slightly motile. The spore position is central to subterminal. No gas vacuoles are observed. The following substrates are utilized as electron donors in the presence of sulfate: formate, butyrate, valerate, caproate, LCFA (see Results), lactate, pyruvate, malate, fumarate, ethanol, methanol, propanol, butanol, isobutanol, pentanol, and $\mathrm{H}_{2}$. Pyruvate and butyrate are incompletely oxidized to acetate and presumably $\mathrm{CO}_{2}$. Acetate and propionate are not used. Pyruvate and lactate are fermented in the absence of sulfate. The electron acceptors include sulfate, sulfite, and thiosulfate. Sulfur is not used as an electron acceptor.

Vitamins are required for growth. Addition of $\mathrm{NaCl}$ is not necessary, but strain $\mathrm{MLF}^{\mathrm{T}}$ tolerates up to $35 \mathrm{~g}$ of $\mathrm{NaCl}$ per liter in the medium; optimal growth occurs in the presence of $15 \mathrm{~g}$ of $\mathrm{NaCl}$ per liter. The temperature range for growth is 35 to $60^{\circ} \mathrm{C}$; the optimum temperature is $50^{\circ} \mathrm{C}$. The optimum $\mathrm{pH}$ for growth is 7.2 to 7.5 .

The $\mathrm{G}+\mathrm{C}$ content of the DNA is $51.2 \mathrm{~mol} \%$ (as determined by ultracentrifugation).

Isolated from a thermophilic anaerobic enrichment culture containing rice hulls grown at $55^{\circ} \mathrm{C}$. The type strain is strain MLF (DSM 6562).

\section{ACKNOWLEDGMENTS}

We are indebted to Y. Combet-Blanc for providing the enrichment culture, P. Sauve for determining the DNA base ratio, M. C. Esteve for technical assistance, and P. A. Roger for revising the manuscript.

Financial assistance from the Griffith University Research Grants Committee and the Australian Research Council Collaborative Grants Scheme to B.K.C.P. is gratefully acknowledged.

\section{REFERENCES}

1. Cord-Ruwisch, R. 1985. A quick method for the determination of dissolved and precipitated sulfides in cultures of sulfate reducing bacteria. J. Microbiol. Methods 4:33-36.
2. Cord-Ruwisch, R., and J. L. Garcia. 1985. Isolation and characterization of an anaerobic benzoate-degrading spore-forming sulfate-reducing bacterium, Desulfotomaculum sapomandens sp. nov. FEMS Microbiol. Lett. 29:325-330.

3. Daumas, S., R. Cord-Ruwisch, and J. L. Garcia. 1988. Desulfotomaculum geothermicum sp. nov., a thermophilic, fatty acid-degrading, sulfate-reducing bacterium isolated with $\mathrm{H}_{2}$ from geothermal ground water. Antonie Leeuwenhoek 54;165-178.

4. De Soete, G. 1983. A least square algorithm for fitting additive trees to proximity data. Psychometrika 48:621-626.

5. Felsenstein, J. 1993. PHYLIP (phylogenetic interference package) version 3.5c. Department of Genetics, University of Washington, Seattle.

6. Hanaki, K., T. Matsuo, and M. Nagase. 1981. Mechanism of inhibition caused by long-chain fatty acids in anaerobic digestion process. Biotechnol. Bioeng. 23:1591-1610.

7. Hungate, R. E. 1969. A roll tube method for the cultivation of strict anaerobes. Methods Microbiol. 3B:117-132.

8. Imhoff-Stuckle, D., and N. Pfennig. 1983. Isolation and characterization of a nicotinic acid-degrading sulfate-reducing bacterium, Desulfococcus niacini sp. nov. Arch. Microbiol. 136:194-198.

9. Jeris, J. S., and P. L. McCarty. 1965. The biochemistry of methane fermentation using ${ }^{14} \mathrm{C}$ tracers. J. Water Pollut. Control Fed. 27:178-192.

10. Jukes, T. H., and C. R. Cantor. 1969. Evolution of protein molecules, p. 21-32. In H. N. Munro (ed.), Mammalian protein metabolism. Academic Press, New York.

11. Love, C. A., B. K. C. Patel, P. D. Nichols, and E. Stackebrandt. 1993. Desulfotomaculum australicum sp. nov., a thermophilic sulfate-reducing bacterium isolated from the Great Artesian Basin of Australia. Syst. Appl. Microbiol. 16:244-251.

12. Marmur, J. 1961. A procedure for the isolation of DNA from microorganisms. J. Mol. Biol. 3:208-218.

13. Meselson, M., and F. W. Stahl. 1985. The replication of DNA in Escherichia coli. Proc. Natl. Acad. Sci. USA 44:671-682.

14. Min, H., and H. Zinder. 1990 . Isolation and characterization of a thermophilic sulfate-reducing bacterium, Desulfotomaculum thermoacetoxidans $\mathrm{sp}$. nov. Arch. Microbiol. 153:399-404.

15. Nazina, T. N., A. E. Ivanova, L. P. Kanchaveli, and E. P. Rozanova. 1989. A new sporeforming thermophilic methylotrophic sulfate-reducing bacterium, Desulfotomaculum kuznetsovii sp. nov. Microbiology (Engl. Transl. Mikrobiologiya) 57:823-827.

16. Olsen, G. J., N. Larsen, and C. R. Woese. 1991. The Ribosomal RNA Database Project. Nucleic Acids Res. 19:2017-2021.

17. Pfennig, N., F. Widdel, and H. G. Trüper. 1981. The dissimilatory sulfate reducing bacteria, p. 926-940. In M. P. Starr, H. G. Trüper, A. Balows, and H. G. Schlegel (ed.), The prokaryotes, vol. 1. Springer Verlag, Berlin.

18. Redburn, A. C., and B. K. C. Patel. 1993. Phylogenetic analysis of Desulfotomaculum thermobenzoicum using polymerase chain reaction-amplified $16 \mathrm{~S}$ rRNA-specific DNA. FEMS Microbiol. Lett. 113:81-86.

19. Roy, F., E. Samain, H. C. Dubourguier, and G. Albagnac. 1986. Syntrophomonas sapovorans sp. nov., a new obligately proton reducing anaerobe oxidizing saturated and unsaturated long chain fatty acids. Arch. Microbiol. 145:142-147.

20. Stabineer, H. 1967. Une nouvelle méthode de mesure précise de la densité des liquides. Monoatsbeste 98:436-438.

21. Szybalski, W. 1968 . Use of cesium sulfate for equilibrium density gradient centrifugation. Methods Enzymol. 12B:330-360.

22. Tasaki, M., Y. Kamagata, K. Nakamura, and E. Mikami. 1991. Isolation and characterization of a thermophilic benzoate-degrading, sulfate-reducing bacterium, Desulfotomaculum thermobenzoicum sp. nov. Arch. Microbiol. 155: 348-352.

23. Van de Peer, Y., and R. De Wachter. 1992. TREECON: a software package for the construction and drawing of evolutionary trees. Comput. Appl. Biosci. 9:177-182.

24. Weng, C. N., and J. S. Jeris. 1976. Biochemical mechanisms in the methane fermentation of glutamic and oleic acids. Water Res. 10:9-18.

25. Werkman, C. H., and H. J. Weaver. 1927. Studies in the bacteriology of sulphur stinkage of canned sweet corn. Iowa State Coll. J. Sci. 2:57-67.

26. Widdel, F. 1980. Anaerobacter Abbau von Fettsäuren und Benzosäure durch neu isolierte Arten Sulfat-reduzierender Bakterien. Ph.D. thesis. University of Göttingen, Göttingen, Germany.

27. Winker, S., and C. R. Woese. 1991. A definition of the domains Archaea, Bacteria and Eucarya in terms of small subunit ribosomal RNA characteristics. Syst. Appl. Microbiol. 14:305-310. 